\title{
SAUL BELLOW AND THE PSYCHOLOGY OF HEARTBREAK: A COMPARATIVE STUDY
}

\author{
Rosalind Buckton-Tucker \\ Assist. Prof. Dr., American University of Kuwait, Kuwait, rjbuckton@yahoo.co.uk
}

\begin{abstract}
"It's terribly serious, of course, but I think more people die of heartbreak than of radiation"' (p. 87) says Benn Crader, the protagonist of Saul Bellow's 1987 novel More Die of Heartbreak. The title can be seen as stressing the power of personal as well as external traumas to shape one's outlook on life. Relationships are sought as a panacea to anxiety but ironically may create the very complications they were intended to mask. This paper will consider More Die of Heartbreak in relation to other novels of Bellow's later period, namely The Dean's December and Ravelstein, to examine similarities and differences of theme. Two of these novels employ a narrator with a close relationship with the protagonist; all three consider a variety of existential questions through the private reflections or conversation of characters seeking a revelation in typical introspective manner, though not without the humour which marks Bellow's work. Likewise, the novels all involve a search for a strategy to cope with the vagaries of life and the approach of death, with the emphasis moving towards the latter as the protagonists grow older in tandem with their author. More Die of Heartbreak, however, chiefly examines, through Crader and the narrator, his nephew Kenneth Trachtenberg, whether love can provide the meaning often lacking in society and life itself. Crader, a botanist, is an expert on Arctic lichens, his subject providing a symbolic escape route via the minutiae of scientific research. Away from his plants, he embarks on and fails in a number of relationships - notably an incongruous marriage to an heiress whose family turns out to have ulterior motives for the union - and questions are raised about the potential confusion of love with lust. The novel also features discussions on topics from the role of the academic to urban violence and decay and to the facing of imminent death, as in The Dean's December and Ravelstein. However, whereas the latter two novels, despite the darknesses contemplated in each, respond to the conundrums of life and death with a hint of optimism, Crader's redemption at the end of More Die of Heartbreak lies in his rejection, temporary at least, of women and of human contact in general and his anticipation of the fulfilment he will find in joining a scientific venture to the North Pole. However, this in itself may be seen as a form of positive thinking and decision-making rather than a passive acceptance of defeat.
\end{abstract}

Keywords: Saul Bellow, heartbreak, love, urban decay, facing death

\section{INTRODUCTION}

Saul Bellow's novels span five and a half decades and numerous political and social changes. While they address a multitude of situations and questions, the one common purpose in each is to find a philosophy of acceptance leading to peace with oneself and the world, and a practical method of addressing personal and universal problems. The protagonists, all individuals who are for one reason or another struggling with their ability to coexist with others and their social milieu, search for a raison d'être to cope with marital and career 
issues as well as the insidious effects of a society which appears to grow gradually more alien and threatening in each novel, sometimes suggesting a breakdown in the values on which the protagonist bases his existence.

Saul Bellow's 1987 novel More Die of Heartbreak comes in the middle of his late period, displaying the concerns of other late novels about society and death, and initially exhibits a similar pessimism in many respects, although with flashes of the Bellow humour which is used at times to confront unpalatable truths. Even the title suggests a sombre outlook on life. More Die of Heartbreak follows his 1982 novel The Dean's December, a novel which is markedly more critical of society and focused on its shortcomings than earlier works, with the exception of the 1970 novel Mr. Sammler's Planet in which Bellow examines social decay in the USA through the eyes of Artur Sammler, an elderly intellectual. However, he then returns to overt comedy with the satirical and irreverent Humboldt's Gift (1975). Apart from three novellas (A Theft (1989), The Bellarosa Connection (1989) and The Actual (1997)) in the intervening thirteen years, More Die of Heartbreak is Bellow's penultimate longer work before his final novel Ravelstein (2000) which has as its topic the facing of imminent death. The three full-length later works, starting with The Dean's December, are worth considering together in order to examine the noticeable similarities and yet their distinct messages, though the following discussion will focus mainly on More Die of Heartbreak.

All Bellow's novels, even those of the darker late period, arguably end on an optimistic note; although the optimism may seem strained at times, there is still an ultimate affirmation of life and an indication of ways to cope with its vagaries. Although More Die of Heartbreak seems to end negatively with Crader's choosing to avoid his worldly problems by participating in a research project in the Arctic, this ending may in fact indicate that there are more ways than one of facing existence and that academic fulfilment is for some a valid and positive answer, whether or not love is present.

\section{NARRATIVE METHOD}

More Die of Heartbreak is narrated by Kenneth Trachtenberg, the nephew of the protagonist Benn Crader, a noted botanist whose specialisation is Arctic lichens. Despite their age difference, Trachtenberg, who has come from Europe to America to look after Crader, putting his own life on hold, describes him as "my closest friend, none closer, virtually the only one" (Bellow 1987, 26. Subsequent references to More Die of Heartbreak will show page numbers only.) Crader, happily married until the death of his first wife Lena fifteen years before, is undergoing a crisis that causes Trachtenberg to assume responsibility for him: "My job - my plain duty - was to hold his head" (11). Since the end of his first marriage, Crader has a history of failed relationships with women, suffers because of an unsatisfactory second marriage and, immersed in his work to an extreme degree, is unable to communicate easily on an everyday level. He is aware of his own shortcomings in this respect: "Suppose I were to have the same ability with people that I have in the field of botany?" (33). Crader is a typical Bellovian protagonist regarding the difficulties of his personal life and his introspection regarding society and existence itself ("Uncle was forever proposing to hold heavyweight conversations" (11)), while Trachtenberg, as narrator, comments on Crader's characteristics without realizing that he, also an academic but a specialist in Russian studies, suffers from the same intellectual preoccupations. Bellow employs a similar narrative method in Ravelstein, in which Chick, the narrator, although some years older, is a close friend of philosopher Abe Ravelstein and has been asked by him to write his biography. Chick examines Ravelstein's life at the same time as commenting on his own, and their discussions are the vehicle for examining the novel's central topic of death, among others. In The Dean's December, on the other hand, the events are narrated from the point of view of the protagonist, Albert Corde, in the third person. While the introspective reflections are similar in nature, the absence of a close confidant as in the other two novels makes for a more sombre tone and an absence of the humour which Bellow often exhibits through the device of dialogue.

\section{LOVE AND HEARTBREAK}

Through this narrator-protagonist interchange of ideas, Bellow has chosen in More Die of Heartbreak to study the nature of love and the particular difficulties caused by the man-woman relationship as his primary topic. Despite, or perhaps as an antidote to, his absorption in his work, Crader has a preoccupation with women, ostensibly a search for love as embodied in his happy first marriage which leads, however, to misguided choices. Trachtenberg observes:

Botany was the big thing. Yet it had a rival, which was female sexuality. He couldn't leave the women alone. When he traveled around the world, his professional cover was roots, leaves, stems and flowers, but actually there was a rival force of great strength. Part of his Eros had been detached from plants and switched to girls. And what girls! (198). 
The start of the novel sets out the problem as seen by Crader, who tells Trachtenberg: "Every life has its basic, characteristic difficulty....One theme developed in thousands of variations....Towards the end of your life you have something like a pain schedule to fill out....But the hardest items of all have to do with love" (11). Crader is at ease in his professional field and exudes the confidence of an authority. Trachtenberg notes: "He was okay in the green. There wasn't much that could hurt Benn the botanist" (115). However, he struggles when it comes to his interactions with women and people in general. Marcus Cunliffe endorses this point, commenting that "[h]is out-of-this-world contemplativeness endows him with an intuitive authority that his nephew calls "the magics"' (xi) but that he displays a limiting naïvety in practical matters.

Trachtenberg relates the story of one of his uncle's emotional entanglements, an encounter with Caroline Bunge, a rich divorcee whom Crader meets in Puerto Rico during one of his lecture trips. "Ready for a permanent connection" (61), she attempts to entice him into marriage by taking an interest in his research and promising assistance by providing a laboratory for him and even accompanying him on expeditions. Trachtenberg observes that, despite Crader's absorption in his work, "[t]he happiness of a recluse wasn't enough for him" (62). Crader tells him, "“I was looking for a Caroline like this, a suitable woman - handsome, responsive, mature"” (79), while his nephew comments, "'Love is a harder subject than lichens"' (80). The relationship progresses to the point where Caroline presents Crader with detailed plans for the wedding, only for him to panic and disappear when love seems to be left out of her calculations. It seems here that Crader enjoys the sensation of being a desirable lover and potential husband, but an instinct for survival, perhaps an ingrained independence, prevents him at the last minute from falling in with plans in which he would in effect be controlled by someone else's wishes and money. He reserves tickets to Tokyo for himself and Trachtenberg at short notice to escape Caroline's arrival prior to the marriage. Trachtenberg agrees to the journey, but privately comments: "But there was something squalid about it - running away from a woman, and such a woman. True, she had picked him. But hadn't he agreed to be picked?" (60) Here, as elsewhere, we see Crader avoiding confrontation through physical distance and a refusal to confront the woman concerned. There are conflicting conclusions to be drawn: on the one hand, Crader's actions could be construed as irresponsible and selfish, while on the other we could argue that Caroline's motivation is selffocused and that Crader deserves better. In either case, his error is in failing to perceive the lack of true communication in the relationship: the difference between his ideal and the reality.

In another example of an unfortunate encounter, Crader allows himself to be seduced by a neighbor, Della Bedell, after she calls on him to help her change a light bulb. Embarrassed and not at first attracted, he is nevertheless unable to deny her. When he tries subsequently to avoid her, she leaves messages: "'When do I get my chance to live!" and: "What am I supposed to do with my sexuality?"' (86). The episode touches on women's sexual liberation, "it was no longer an impropriety...to take the initiative" (85) and raises the question of the implications of easily accessible sex without love. Trachtenberg, analysing the incident, comments that people look at sex as a remedy for all difficulties: "'they do the act by which love would be transmitted if there were any"' (86), contrasting the traditional view of sex as an act of love and for procreation with the difference in attitude in present-day society. When Della dies of a cardiac arrest while Crader is away lecturing in Brazil, he is immediately remorseful, though Trachtenberg tries to persuade him to see the light bulb incident in proportion and even to acknowledge humour in the situation. It is around this time that Crader says, in response to a journalist's question about radiation levels, "I think more people die of heartbreak than radiation" (87).

Trachtenberg duly accompanies his uncle to Tokyo, where one evening the junior colleagues of Crader's host, Professor Komatsu, invite Crader and Trachtenberg to a striptease show. The ensuing performance by a number of young girls, leaving nothing to the imagination, presents forcefully the phenomenon of organised voyeurism: "All these botanists, engineers, inventors of miraculous visual instruments from electron microscopes to equipment that sent back pictures of the moons of Saturn, cared for nothing but these slow openings. They couldn't look enough" (108). The incident appears to indicate a universal susceptibility, regardless of intellect, to sexual titillation at a basic level. This scene portrays the other end of the spectrum from the spiritual communion sought in a love relationship and serves as a harsh reminder of the dark side of physical attraction and of the degradation of women employed in such a spectacle. Trachtenberg remarks on Crader's troubled reaction: "And now he was in his fifties, and still tormented, a full-scale example of the ordeal by desire" (110) and surmises that the event unsettled his uncle to the extent that "he determined to settle his life once and for all" (111) by marrying for a second time without even informing his nephew, despite their close relationship. Crader believes, mistakenly as it proves, that through this marriage he will find harmony between love and desire and the fulfilment of his search for a true accord.

Early in the novel, Trachtenberg reflects on the preoccupation with seeking happiness through love: "The question then is: So why does everybody persist? If love cuts them up so much, and you see the ravages everywhere, why not be sensible and sign off early?" (11). Faye Kuzma comments: "That question informs 
and haunts every page of More Die of Heartbreak (161)"'. The novel appears to show that instinctive emotional need often prevails over logic and that, since the quest for a partnership is a universal and unchanging aspiration, all one can do is to approach it with careful judgment and awareness; the possibility of pain can never be eliminated but can be lessened.

\section{MATERIALISM AND URBAN DECAY}

As well as the nature of love, Bellow contemplates the human trait of acquisitiveness and the urban problems that have featured in earlier novels. These are illustrated when Trachtenberg muses at length on Crader's second marriage to Matilda Layamon, a beautiful PhD student in her thirties with a rich physician for a father, wondering why he should have chosen to commit himself to a permanent relationship. He concludes that despite his work on plants, which takes most of his energies and has brought him acclaim, his affectionate side craves fulfilment:

Emotional types, loving hearts like my uncle, exuberant high-energy characters, easily agitated, needy, greedy - they can't see why one high gift should not be followed by another, by a succession of gifts. The demand then was for a sharer, a charming woman, such a woman as Swedenborg describes - made by God to instruct a man, to lead him to the exchange of souls (54).

He explains that the exchange of souls, according to Swedenborg, the $18^{\text {th }}$ century philosopher and theologian, occurs when the affection of a woman meets the abstract tendencies of a man and "[l]ove and thought complete each other in the human pair" (50). However, when Crader tells Trachtenberg, "I really love Matilda. She's the greatest" (119), his nephew is sceptical of her intentions, and, indeed, Crader soon discovers that material considerations are uppermost in her family. His role, according to Trachtenberg, is supposed to be as "a botanist to be a host to celebrities - the spouse who went with the house" (155). For their home, Matilda intends to renovate a grand but old-fashioned apartment left to her by her aunt, creating doubts in Crader: "'The living room could be the hangar for two, three private planes. Her lifetime plan for married happiness included these - what looked to me like museum halls. It's a three-cornered match: Matilda, me and the Roanoke [the apartment building]"' (154). At a luncheon with Matilda's father, Crader learns that he wants him to reopen a case against Harold Vilitzer, Crader's uncle, who has made a fortune through the sale of what becomes the site for the Japanese-owned Ecliptic Circle Electronic Tower, a vast skyscraper and local landmark. He purchased the land from Crader's family through a bogus company, swindling them out of its real value. Any compensation will, of course, enrich Matilda as Crader's wife. Before the case can be completed, Vilitzer dies in the midst of the legal wrangle.

The Electronic Tower is symbolic both of urban development and a materialistic society; Gary Davenport observes that "money, or the lack of it, has always been and continues to be thematically central to urban fiction" (698). Trachtenberg sees Crader's choice of career as a way to counteract urban oppression, "the heavy burdens of social development imposed on the soul" (279). The earlier novel The Dean's December reflects even more strongly Bellow's focus on social ills, describing both the criminal life of Chicago and the corruption of the political regime in Bucharest and the effect of each on the existence of the individual. While in More Die of Heartbreak the discussion is not as overt, the background of urban America is nonetheless present throughout the novel: "All those abandoned industries awaiting electronic resurrection, the colossal body of the Rustbelt, the stems of the tall chimneys nowadays bearing no blossoms of smoke" (146). There is an implied contrast with Crader's career choice of the natural world and his satisfaction in studying its minute workings: the pure versus the corrupt?

\section{ESCAPE OR SELF-PRESERVATION?}

In a decisive move, Crader, who is due to meet Matilda in Rio for a lecture tour of Brazil, changes his plans at the last moment, feeling that the marriage has run its course. As with Caroline, his expectation of happiness differed from the reality. He implements his decision to separate from Matilda by joining a research project at the North Pole:

"And nothing but night and ice will help me now. Night so that I can't see myself. Ice as a corrective. Ice for the rigor. And also because there'll be no plants to see, except the lichens. Because if there's no rapport, if the rapport is dead, I'm better off in plant-free surroundings....It's a survival measure" (334).

He declines Trachtenberg's offer to obtain legal assistance in the event of Matilda's requesting an annulment of the marriage, not wishing to mount a defence, and tells his nephew that he is the only person he will miss. On the surface, Crader's decision may appear to be a rejection of life and human relationships and to indicate that he has not learnt or progressed from his previous failures. On the other hand, his assertiveness 
can be construed as self-recognition in which he acknowledges the difference of his nature and chooses to deploy his special gift in botany as a worthwhile end in itself. Further, the expedition will, though its timescale is indefinite, eventually come to an end, and Crader's escape is thus temporary, as he knows. In a reference to the phoenix, he says, "'Well, let's see what can be done, whether I can rise from these ashes"' (334-5). While acknowledging that any change is unlikely at present, he at least leaves the possibility open. In the meantime, he is following the path of the academic, opting for the theoretical over the practical, and, however apparently remote from life the research topic, exhibiting the curiosity for discovery which is essential to a developed society and which, indeed, mirrors that of most Bellovian protagonists. Bellow could be telling us that we need the Craders, the Cordes and the Ravelsteins of this world for our intellectual growth and indeed for our survival.

\section{PARALLELS BETWEEN PROTAGONIST AND NARRATOR}

Trachtenberg himself has problems with relationships which parallel Crader's to some extent. He is preoccupied with his involvement with a young woman, Treckie, by whom he has a daughter but whose behaviour towards him is elusive. Ellen Pifer observes that "[w]ith his uncle, a widower, Ken shares a propensity for ineffectual and "confused relations with women"; he cannot even persuade Treckie, the "childlike" but willful young woman he adores, to marry him" (154). Treckie eventually marries Ronald, a snowmobile salesman, to Trachtenberg's bewilderment and anger. Through these details Bellow creates a role for Trachtenberg as a distinct character with his own troubles rather than just a narrator and analyst, and also provides comparisons to Crader's situation. Gerhard Bach remarks that "[b]oth subscribe to the dream of living peacefully -- "Two human beings bound together in love and kindness" -- and both are shocked, and then plunged into confusion, when their respective women give them such drubbings" (296). The similarities are numerous, as Wendy Lesser points out:

In describing the adventures of his beloved Uncle Benn - his enthusiasms and achievements in the field of botany, his naivety in the world of business and politics, his disastrous marital alliance to the grasping Matilda Layamon and her even more grasping father - Kenneth also presents himself: his own failed loves and successful studies, his own familial affections and deep-seated dislikes (664).

As Elaine Safer has stated, there is a comic irony in the constant search of the pair for fulfilling relationships as relief from their analytical pursuits. She refers to the shortcomings of the academic mind in this respect: "The gap between their intellectual aspirations and their social relationships forms basic incongruities that create much of the irony in the novel" (216). We could ask whether Crader's extreme absorption with his academic studies is responsible for his inability to sustain a harmonious relationship or indeed to understand its requirements. We are reminded of Herzog, Bellow's protagonist in his 1964 novel of that title, another introspective academic suffering from failure in marriage and a series of ambivalent relationships. A connection is suggested between such protagonists' characters and their difficulties in relating to women; intellectual prowess seems to detract from emotional judgment.

\section{DEATH AND LOVE}

As are love relationships, facing death is a recurring topic throughout Bellow's works. It is discussed in the earlier novels in a somewhat different tone to that of the later ones; for instance, Bellow describes Humboldt's Gift as "a presumptuous book which attempts to make a comedy of death" (cited in Bragg 1975, 676). While Ravelstein is the late novel which most directly addresses the problem of the foreknowledge of death, especially when known to be imminent through either age or illness, both The Dean's December, where the plot is built largely around the forthcoming death of Corde's mother-in-law Valeria, and More Die of Heartbreak raise the issue. Crader believes that "The big win is to cheat death. Hold it at bay" (327). Asked by Trachtenberg how he imagines death, he replies, "'Well, from the very beginning there have been pictures - inside and outside....And for me the worst that can happen is that those pictures will stop"' (19). The phrase, "The worst that can happen" suggests that oblivion is only one possible scenario and that the existence of an afterlife cannot be totally discounted. This foreshadows Chick's comment in Ravelstein, "No one can give up on the pictures - the pictures might, yes they might continue" (Bellow 2000, 222). In More Die of Heartbreak, love is linked to death; Trachtenberg muses during the flight to Tokyo:

We might imagine that we had left the earth behind. We were still, however, within the mundane egg where all creatures, all beings, lived on death, infected by death in the very desire for love, the only force that held out a hope against being devoured altogether (89).

Love, it could be argued, is a way of coming to terms with death through the reassurance engendered by a strong relationship and the sense of purpose in providing mutual support. Trachtenberg's comment apropos 
of Crader's marriage to Matilda, "We have to die, some sooner than others, and as condemned men, it's only natural to try for peace - two human beings bound together in love and kindness, and so forth" (120), bears out this idea.

\section{CONCLUSION}

In Crader's case, his attempts at finding love have not succeeded, and his rejection of his marriage to Matilda mirrors his earlier flight from Caroline. In each case he puts a symbolic physical distance between himself and the women - travelling in one instance to Tokyo, in the other to the Arctic. The similarities pose the question of whether Crader is acting as a coward or judiciously putting an unambiguous end to his partners' expectations. The difference is that with Caroline the marriage is only forthcoming, but in Matilda's case Crader is denying the future of an existing marriage. However, in both cases, the message may be that, if love is, or has become, absent, a realistic response is the courageous one, notwithstanding marriage vows. Crader's decisive action to end his relationship with Matilda can even be construed as a positive step in terms of his self-knowledge and the fact that Matilda's mercenary considerations prompted the marriage; there will be no 'heartbreak' for Matilda other than humiliation and the thwarting of her and her family's plans.

More Die of Heartbreak, then, fits the pattern of other Bellow novels where life issues are confronted and the protagonist finds a way forward, accepting the imperfect and seeing hope for the future in a new approach to his concerns. However, its ending differs from the more optimistic ones of the earlier novels and those of the two other late novels. The Dean's December concludes with a symbolic journey towards the stars in an observatory and Ravelstein indicates a possible approach to the existential fear of death, creating the note of optimism on which Bellow customarily ends his novels.

Does Bellow, though, provide an answer to rather than just a statement of the problematic nature of love? Through Crader's unsteady progression from one 'love' object to another, it may be the need for discernment that is suggested. His happy marriage to Lena suggests by its inclusion in the story that good relationships are possible and love a worthwhile goal; it is implied that only Crader's lack of judgment prevents him from finding contentment a second time. Love, elusive and highly complex, is an eternal preoccupation and Bellow rightly does not attempt to suggest an easy formula for success. Rather, he implies that one should be true to oneself and not accept a flawed relationship for the sake of companionship only. Fulfilment comes in different forms to different people, and it is indicated that it is as worthwhile to pursue a specialised career as to opt for marriage. However, the one does not necessarily exclude the other, and at no time is it suggested that a genuine love relationship is not a possible attainment. If absence of denial signifies hope, Crader may still have the chance to find happiness outside the Arctic.

\section{REFERENCE LIST}

Bach, Gerhard. The Critical Response to Saul Bellow. Westport: Greenwood Press, 1995.

Bellow, Saul. Ravelstein. New York: Penguin Books, 2001.

Bellow, Saul. More Die of Heartbreak. New York: William Morrow, 1987.

Bellow, Saul. The Dean's December. London: Secker \& Warburg, 1982.

Bellow, Saul. Humboldt's Gift. New York: Viking Press, 1975.

Bellow, Saul. Mr. Sammler's Planet. New York: Viking Press, 1970.

Bellow, Saul. Herzog. New York: Viking Press, 1964.

Bragg, Melvin. "Off the Couch by Christmas." The Listener 96: 675-6. From an interview in Second House, BBC2, 15 November 1975.

Cunliffe, Marcus. "Saul Bellow's Family Affairs." The Washington Post, June 7, 1987, Book World: xi.

Davenport, Gary. "Urban Fiction Today.” The Sewanee Review, Vol. 96, No. 4 (Fall 1988): 695-702.

Kuzma, Faye. "The Demonic Hegemonic: Exploitative Voices in Saul Bellow's More Die of Heartbreak." Critique 39.4 Summer 1998: 306-323. 
Lesser, Wendy. "Serious Comedy." The Hudson Review, 40.4 (Winter, 1988): 661668.

Pifer, Ellen. Saul Bellow Against the Grain. Philadelphia: University of Pennsylvania Press, 1990.

Safer, Elaine B. "From Poem to Cartoon: Comic Irony in More Die of Heartbreak." Critique 34.4 Summer 1993: 203-219. 